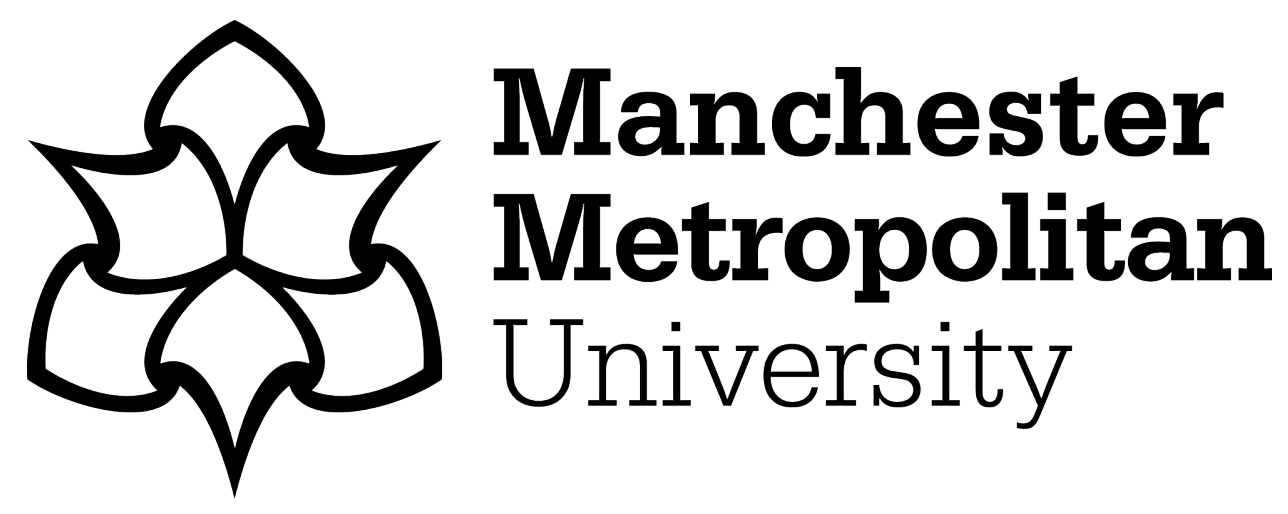

Caiado, RGG, Quelhas, OLG, Nascimento, DLDM, Anholon, R and Leal Filho, W (2019) Towards sustainability by aligning operational programmes and sustainable performance measures. Production Planning and Control, 30 (5-6). pp. 413-425. ISSN 0953-7287

Downloaded from: https://e-space.mmu.ac.uk/623047/

Version: Accepted Version

Publisher: Taylor \& Franics

DOI: https://doi.org/10.1080/09537287.2018.1501817

Please cite the published version 


\title{
Towards sustainability by aligning operational programmes and sustainable performance measures
}

\author{
Manual Caiado R G G, Quelhas OLG, Nascimento DLDM, Anholon R, Leal Filho \\ W
}

Production Planning and Control 30(5-6):413-425 26 Apr 2019 DOI

https://www.tandfonline.com/doi/full/10.1080/09537287.2018.1501817

\begin{abstract}
In the last decades, sustainable concerns have increasingly gained importance to organizational survival and Lean/Six Sigma approaches are becoming more and more outstanding in order to improve sustainability performance. This paper aims to evaluate the degree of importance of sustainable performance measures of Brazilian organizations and to propose guidelines to achieve sustainability aligning these measures with operational improvement programmes. Multiple data collection methods were applied as theoretical literature review, questionnaire survey and semi-structured interviews with industry professionals and academic researchers. The findings show that it is the corporate responsibility to focus their efforts on both operational improvement programmes and sustainable initiatives in order to achieve better environmental protection, corporate reputation, quality management, cost performance and suppliers relations, as they are considered to be more important on organizational sustainability.
\end{abstract}

Keywords Survey, Organizational sustainability, Performance measures, Sustainable development, Lean Six Sigma

\section{Introduction}

In the current context, the increasing industrialization and scale of economic activity have significantly shaped modern life and the physical and social world in which we live (Caiado, Dias, et al. 2017). This transformation of resources from the Earth into wealth through industrial activity has led to an increasing level of consumption of materials and energy, a trend that has been one of the fundamental drivers of global and local environmental change and which has led to adverse consequences for ecosystems and societies (Linnenluecke and Griffiths, 2013; Caiado et al. 2017; Caiado et al. 2017).

The paradigm of the 21 st century is to enable organizations to relate otherwise to the environment in which they coexist (Elkington, 1998), or through the adoption of sustainable principles that in addition to generating environmental and social benefits will bring improvement in economic value of the organization (Fiksel et al, 1999), and the impetus for corporate social responsibility that lead to the creation of decision-making tools geared to social impacts (Hutchins and Sutherland, 2008). 
Previous researches has investigated the relationship between measurement practices with sustainability performance (Norman and Macdonald, 2004; Labuschagne et al. 2005; Adams et al. 2014) and the importance of operations and quality improvement methodologies, such as Lean Manufacturing (LM) among others to influence "Green" initiatives (Garza-Reyes 2015), including their actions to a better performance (Verrier et al. 2014). However, there are no standardized methods for assessing sustainability in manufacturing processes and no consensus on which indicators should be used (Helleno et al. 2016).

In general, earlier studies are focussed on some of the dimensions of sustainability, and fewer studies present a simultaneous approach that takes into account the three dimensions of Triple Bottom Line (TBL) proposed by Elkington (1998) (Morioka and Carvalho 2014) with effective sustainable performance measures (Hourneaux Jr. et al. 2014). However, there is lack of practical studies, especially in an emergent economy like Brazil, that evaluates the importance of performance measures aligned to operational and TBL dimensions to simultaneously achieve operational excellence and sustainability objectives and highlight the integration of operational improvement programmes into sustainable performance measures. This combination seems logical, but a question arises from this: How effectively achieve sustainability through alignment of key sustainable measures and operational improvement programmes? To answer this question and the emerging gaps, the objective of this paper is threefold:

(1) assess the degree of importance of sustainable performance measures for the organization's sustainability;

(2) investigate the key sustainable performance measures to achieve sustainability

(3) find out the impact of operational improvement programmes to handle the key sustainable measures and achieve more sustainable production and services;

The research has responded to the growing need for sustainable performance measures, which are aligned with TBL (economic, environmental, social), technical (operational) and governance dimensions of sustainability in order to ensure greater comprehensiveness and robustness in supporting the decision-making process. It also aims to bridge the knowledge gap on sustainable performance measures by comparing the state of the art with the results of an applied study. This study provide both academics and practitioners a better panorama to understand the alignment of the key sustainable performance measures and operational improvement programmes and these analyses can serve as benchmarking for future corporate sustainability operations and strategies. The 
main contribution of this paper is the proposal of guidelines which highlights the integration and alignment of operational improvement programmes into sustainable measures to aid organisations to balance the need for operational excellence in their production and service systems with environmental commitment and social fairness.

\section{Literature review}

\subsection{Performance measures towards sustainable development}

In the last two decades, much has been written on the principles of sustainable development and the need for organizations to build on sustainable practices which drastically change the way in which they conduct business (Linnenluecke and Griffiths 2013), creating great impact on the performance of companies (Yusuf et al. 2013). From the literature (Garza-Reyes 2015), it can be inferred that there is much pressure towards the transition of organizations and industries to sustainable development.

Adams et al. (2014) stresses that the increase of care in the performance evaluation by managers, consultants and academics is a reflection of the increase in pressure on organizations to improve on sustainable development. Concerning the pressure within organizations, Schrettle et al. (2014) state that the cultural influence through motivation, disseminating information, and management commitment with sustainability in the long term. On regulatory, competitive and market pressure, the increase in the consumption of materials and energy can be highlighted, leading to adverse consequences to ecosystems and to societies. (Linnenluecke and Griffiths 2013), followed by the need for environmental protection and the increase in demand for natural resources $(\mathrm{Wu}$ and Pagell 2011). Furthermore, and meanwhile, new policies and shapes of environmental regulation come up, which determine the type of technology that may be used, potentially creating economic structures to redistribute environmental costs and benefits (Etzion 2007).

Moreover, organizations with good performance may utilize their efforts in proactive environmental transparency, as a way of achieving more objective and verifiable communication of the current operational capacity and their good performance, aiming to improve corporate image and to gain a green competitive advantage (Meng et al. 2014). Epstein and Roy (2001) state that many organizations have developed performance evaluation systems to aid in measuring the sustainable performance of organizations, business units, facilities, teams, managers and all other employees. The effective measurement of environmental performance has been a challenge to organizations, and a crucial aspect for accomplishing this task is the appropriate definition 
of measurements as well as the utilization of environmental performance indicators (Hourneaux Jr. et al. 2014). The measurement of performance is important not only for understanding the changes which seem to be caused by sustainability, but also for clarifying the process for other companies (Leite et al. 2011). In the Table 1, some of the main sustainable measures have been selected from the performance measurement literature.

Table 1. Main sustainable performance measures

\begin{tabular}{|c|c|c|}
\hline Code & $\begin{array}{l}\text { Sustainable performance } \\
\text { measures }\end{array}$ & Researchers \\
\hline M1 & Cost performance & $\begin{array}{l}\text { Nagalingam, Kuik, and Amer (2013); Luzzini et al. } \\
\text { (2015); León and Calvo-Amodio (2017) }\end{array}$ \\
\hline M2 & $\begin{array}{l}\text { Environmental and social } \\
\text { performance }\end{array}$ & $\begin{array}{l}\text { Silva, Vaz, and Ferreira (2013); Luzzini et al. (2015); } \\
\text { Helleno, de Moraes, and Simon (2016); Gandhi, Thanki, } \\
\text { and Thakkar (2018) }\end{array}$ \\
\hline M3 & $\begin{array}{l}\text { Inter-firm collaborative } \\
\text { capabilities }\end{array}$ & Luzzini et al. (2015); \\
\hline M4 & $\begin{array}{l}\text { Intra-firm collaborative } \\
\text { capabilities }\end{array}$ & Luzzini et al. (2015); \\
\hline M5 & Environmental protection & $\begin{array}{c}\text { Valiente et al. (2012); Verrier et al. (2016); Fu, Guo, and } \\
\text { Zhanwen (2017) }\end{array}$ \\
\hline M6 & Employee satisfaction & $\begin{array}{c}\text { Fiksel et al. (1999); Singh et al. (2007); Valiente et al. } \\
\text { (2012); Golini et al. (2014); Helleno et al. (2016); León } \\
\text { and Calvo-Amodio (2017) }\end{array}$ \\
\hline M7 & Supplier relations & Valiente et al. (2012); Verrier et al. (2014) \\
\hline M8 & Corporate reputation & $\begin{array}{c}\text { Golini et al. (2014); Galeazzo et al. (2014); León and } \\
\text { Calvo-Amodio (2017) }\end{array}$ \\
\hline M9 & Environmental logistics policy & Ciliberti et al. (2008) \\
\hline M10 & Quality management & $\begin{array}{l}\text { Valiente et al. (2012); Godinho Filho, Ganga, and } \\
\text { Gunasekaran (2016); Prasad, Khanduja, and Sharma } \\
\text { (2016) }\end{array}$ \\
\hline M11 & Social benefits, medical-legal & Valiente et al. (2012) \\
\hline M12 & Customer satisfaction & $\begin{array}{l}\text { Valiente et al. (2012); Godinho Filho et al. (2016); León } \\
\text { and Calvo-Amodio (2017) }\end{array}$ \\
\hline M13 & $\begin{array}{l}\text { Balancing professional and } \\
\text { family life }\end{array}$ & Valiente et al. (2012) \\
\hline M14 & Transparency in information & $\begin{array}{c}\text { Valiente et al. (2012); Lee and Saen (2012); Ahuja, } \\
\text { Sawhney, and Arif (2016) }\end{array}$ \\
\hline M15 & Green Marketing & Jabbour et al. (2013); Thieme et al. (2015) \\
\hline M16 & Environmental Policy & Miller et al. (2010); Puvanasvaran, Tian, and Vasu (2014) \\
\hline M17 & Investor Relations & Lee and Saen (2012) \\
\hline M18 & $\begin{array}{l}\text { Representation and dialogue with } \\
\text { employees }\end{array}$ & Valiente et al. (2012); Verrier et al. (2014) \\
\hline M19 & Code of conduct & $\begin{array}{c}\text { Kocmanová and Šimberová (2016); Campos and } \\
\text { Vazquez-Brust (2016) }\end{array}$ \\
\hline M20 & Corporate Governance & $\begin{array}{c}\text { Lee and Saen (2012); Vlachos (2015); Kocmanová and } \\
\text { Šimberová (2016) }\end{array}$ \\
\hline M21 & Labor practice indicators & Kocmanová and Šimberová (2016) \\
\hline
\end{tabular}


M22 Human capital development

M23 Support of social setting

M24 Energy conservation

M25 Sustainable working condition

M26 Carbon footprint reduction

M27

Reduction in amount of energy use

M28 Reduction of air pollution

M29 Waste management

M30 Reduction in amount of resource use

M31 Sources of recyclable raw material
Singh et al. (2007); Ciliberti et al. (2008); Zhan et al.

(2015)

Valiente et al. (2012); Lee and Saen (2012)

Dhingra et al. (2014); Thieme et al. (2015)

Fiksel et al. (1999); Yusuf et al. (2013); Camuffo and Stefano (2017)

Fiksel et al. (1999); Yusuf et al. (2013); Fercoq, Lamouri, and Carbone (2016); Garza-reyes, Villarreal, and Kumar (2017)

Yusuf et al. (2013); Nagalingam et al. (2013); Verrier et al. (2016); Fu et al. (2017)

Vinodh et al. (2011); Yusuf et al. (2013); Garza-reyes et al. (2017)

Vinodh et al. (2011); Yusuf et al. (2013); Thieme et al. (2015); Helleno et al. (2016); Verrier et al. (2016); León and Calvo-Amodio (2017)

Fiksel et al. (1999); Yusuf et al. (2013); Nagalingam et al. (2013); Verrier et al. (2016); Fu et al. (2017)

Fiksel et al. (1999); Yusuf et al. (2013); Nagalingam et al. (2013)

Table 1 depicts the existence of a great diversity of performance indicators, each group being more adequate to a specific context or analysis field. The conceptual idea of performance measurement in sustainability consists in collecting measurable and trackable data from companies in which a pivotal challenge is the generation and dissemination of robust, relevant, accurate and feasible information for decision making (Olsthoorn et al. 2001; Jin and High, 2004).

Besides that, sustainability measures can affect the choice of quality improvement programmes (Chugani et al. 2017), as this new concepts and approaches should direct companies to more efficiently operations, with less waste and commitment to deliver the triple bottom line. By adopting a Green perspective, organizations can become more productive and efficient, increasing their profits and reputation (León and Calvo-Amodio 2017). As Garza-reyes, Villarreal, and Kumar (2017) nowadays environmental sustainability must be aligned to the traditional priorities of profitability, efficiency, customer satisfaction, quality, and responsiveness. Therefore, we hypothesize the following:

H1. There is a positive relation between socio-environmental measures and quality management; 
2.2 Synergies and divergences between sustainability initiatives and operational improvement programmes

In a rapidly changing environment, organizational survival depends not just on it operating in the most profitability, effective and efficient manner possible, but also on its compromise with environmental regulations and social demands and the adoption of evolving strategies (Garza-Reyes 2015) For this reason, operational improvement programmes, as LM, Six Sigma and Lean Six Sigma are becoming more and more outstanding in order to improve sustainability performance and underpin competitive advantage.

Lean Manufacturing was founded under the leadership of Taiichi Ohno at the Toyota Motor Company in the 1950s to reduce wastefulness, achieve an engaging approach in the relationship between employees, suppliers and customers; Six Sigma was created by Bill Smith at Motorola Corporation, in the 1980s, seeking to reduce errors and defects; and Lean Six Sigma emerged in the late 1990s and early 2000s, incorporating Lean's principles of speed and immediate action with the Six Sigma vision of flawless quality and reducing the impact of variation on queue times, being a mechanism that seeks the engagement of everyone for joint reach and no trade-offs of quality, speed, and cost (George 2002).

The literature suggests that those approaches make a positive contribution to the sustainable performance of organisations and offer a better culture to deploy sustainability philosophies, tools and methods (Powell et al. 2017; Cherrafi et al. 2017). Lean practices has some synergies with sustainability as waste reduction, reduction of environmental impacts such as emissions into the air, water and soil, as well as efficiency of water and conservation of energy, creation of greener supply chains, lead time reduction, product design and techniques to manage people (Chiarini 2014; Garza-Reyes 2015; Chugani et al. 2017), and this actions could be enhanced when used together (Verrier et al. 2014).

Moreover, it can be seen that Six Sigma aims to reduce defects and cost by controlling the necessary resource consumption (Chugani et al. 2017) and can contribute to improve sustainable production and service systems, because through its principles firms can manage energy use and implement, manage, sustain and improve sustainability performance (Garza-Reyes 2015), as DMAIC cycle (Define, Measure, Analyze, Improve and Control) could make suitable to measure sustainability. 
In addition to, Lean Six Sigma represents a cultural transformation that makes organizations consider and accept environmental innovation and can reduce marginal cost of sustainability initiatives (Cherrafi et al. 2016). Their techniques also contribute to a more environmentally sustainable supply chain and improve process performance (Powell et al. 2017). In fact, Lean and Six Sigma are catalysts for the implementation of sustainability in manufacturing companies (Verrier et al. 2014). However, there are also some obstacles for corporate sustainability, such as the supply relationship, a critical part in LM (Simpson and Power 2005) and the supply of human and material resources for implementing sustainable processes. As LM is an integrated approach that incorporates a wide variety of practices, including supplier management (Shah and Ward 2003), the supplier development requires the firm's commitment with financial, capital and personnel resources, as well as, their collaboration and compliance (Simpson and Power 2005).

Thus, there are compatibilities and complementarities between those emergent manufacturing practices (Thomas et al. 2016) and sustainability in terms of waste elimination and efficient use of resources, continual improvement and implementation strategies, measurement metrics, supply chain relationships, satisfying customer needs and tools and practices (Cherrafi et al. 2016; Chugani et al. 2017). Taking into account the above arguments, and the results obtained in previous studies, we also want to examine the following hypothesis:

H2. There is a positive relation between supplier relations and customer satisfaction;

On the other hand, unlike sustainable initiatives, Lean and Six Sigma approaches don't consider social and governance dimensions of sustainability and neither the lifecycle and don't pay attention to the sustainable value of products or the environmental risk of the materials transformation processes used to produce products (Cherrafi et al. 2016).

Sagnak and Kazancoglu (2016) emphasized the need for the application of Six Sigma methodology to the Green Lean approach in order to fill up its gaps and assess performance. Therefore, as there are divergences between sustainability and operational improvement approaches - Lean aims to reduce waste, Six Sigma aims to achieve continuous improvement of quality by minimising the defects and Green aims to decrease the negative ecological impacts (Kumar et al. 2016) - the integration between those approaches are necessary in order to aid organisations to balance the need for operational efficiency in their production and service systems with environmental commitment and social fairness. 
Furthermore, its essential to integrate those programmes with measurement system and control techniques to satisfy the need for measurement (Sagnak and Kazancoglu 2016). Verrier et al. (2014) proposed a framework to measure both productivity and environmental performance, including indicators for integrating Green and Lean to improve economic, environmental and social performance, allowing the companies to measure their ability to run a Lean and Green policy and benchmark their practices and experiences with other companies. Helleno et al. (2016) contribute to the current sustainability assessment methods by developing and applying a method to integrate a new group of sustainability key performance indicators (KPI) based on the TBL concept into the Value Stream Mapping - Lean manufacturing tool - (Lean KPIs) to assess the manufacturing process parameters in Brazilian industry. The method helps to measure the parameters that influence the productivity and thereby promote the improvement of sustainability. Therefore, sustainable organizations can integrate and align operational improvement programmes into their sustainability strategies through development of assessment models and measures that effectively contribute to increasing sustainability in manufacturing processes. Because of that, the effectiveness of a Performance Measurement System (PMS) is important, being able to provide an indication of the current market position of the organization, and to aid in the development of future operations and strategies (Langfield-Smith et al. 2009). Furthermore, to Veleva and Ellenbecker (2001), these PMS may facilitate the creation of a more ecoefficient and socially responsible production system, which aims to foster sustainable manufacturing.

However, there are some challenges to implementing Green and Lean Six sigma regarding expertise training programme, support of management, customer involvement and the adequate technologies, facilities, human resources, time management and organizational culture (Kumar et al. 2016).

\section{Research Methodology}

The explorative research study adopted a triangulation method with qualitative and quantitative data collection mechanisms to operationalise the research questions and constructs (Yusuf et al., 2013). As triangulation involves using more than one method to gather data, in our study we used three mechanisms: (1) a literature review; (2) a survey conducted across fifty industry professionals; and (3) semi-structured interviews with eleven academics. The use of different methods through the data triangulation to study 
the same phenomenon increases the validity of the research results (Psychogios and Tsironis 2012).

In addition, it may be observed that the research also counts on multiple sources of information (source triangulation) such as content analysis of articles, questionnaires survey, interview and direct observation and iteration with the constructs developed from the literature, which enables further constructive validity (Eisenhardt 1989); To Miguel (2005), the use of multiple sources allows for the support of the constructs, propositions or hypotheses, in other words, the technical use of triangulation helps in the iteration and convergence between various sources of evidence.

\subsection{Survey design, sampling and data analysis}

The first step consists of an extensive literature review of the sustainable performance measures, in order to support the design of the research survey. As in the work of Sureeyatanapas et al. (2015), in this review, 31 measures were preliminary identified by examining works focusing on the manufacturing sector in general, rather than on a specific industry, in order to cover the general concerns within the field. These identified measures are then evaluated by the organizations.

The second step seeks to enhance the power of generalization of the relevance of the sustainable measures across the perception of a wide range of professionals working in the industry. A survey was conducted with industry professionals on August of 2016 in order to verify which sustainable measures are most important to organizational sustainability. Prior to sending out the questionnaire, a pilot study was undertaken in order to eliminate potential problems. A draft of the survey questionnaire was reviewed by four industrial practitioners experienced in sustainability to offer a better refinement of the questions, ensuring that experts would have no difficulty in answering the questions. In order to organize the questionnaire in a logical sequence and to better understand the subject studied, the survey questionnaire consists of two parts. The first part was intended to determine the demographical details of the participating experts, and the second part aimed to measure the importance of sustainable performance measures for organizations in which the specialists worked. All responses on the importance of sustainable measures items were recorded using a five-point Likert-type scale (1 - "very low" to 5 - "very high").

The intended population of this survey consists in public and private sector professionals who were present during a Conference on Sustainable Management in the 
city of Rio de Janeiro, but who work in companies or institutions throughout various regions of Brazil. Given that the true characteristic of the intended population was unknown; convenience sampling was performed (Sekaran and Bougie, 2010), because this research aims to test the relationships of variables (Calder et al. 1981). The research sample, a total of 50 questionnaires, was collected and after the manual screened check of the data, ignoring those with incomplete questions, this resulted in $30(60 \%)$ valid questionnaires. As Hines and Montgomery (1990) and Sureeyatanapas et al. (2015) point out, in small populations, a sample of at least 30 usable responses for every part of the questionnaire enables a reasonable statistical analysis of the data. The majority of the respondents work in organizations which adopts sustainable measures (86.7 percent) and have master's degrees (56.7 percent).

The data analysis was done using the $\mathrm{R}$ software ( $\mathrm{R}$ Development Core Team, 2017). Descriptive statistics were used, including frequencies / percentages to describe sample characteristics analyzed and we verified the degree of importance of the measures, obtaining an average ranking based on the weighted frequency (WF) of the scores attributed to the answers by the following Equation (1):

$$
\text { Weighted Frequency }(W F)=\sum\left(f_{i} \times W_{i}\right)
$$

Where:

- $f_{i}=$ observed relative frequency of each response to each measure

- $W_{i}=$ weight value of each likert scale response

The reliability of the variables was assessed based on the value of the Cronbach's alpha coefficient, which is one of the main ways of estimating the internal consistency of each construct in a questionnaire (Forza, 2002), and should reach the minimum level of 0.70 and can admit 0.60 in exploratory research (Hair Jr et al., 2009). Then, to check the data normality, Lilliefors (LF) and Anderson-Darling (AD) normality tests were applied. According to Razali and Wah (2011) LF test always outperforms Kolmogorov-Smirnov test and $\mathrm{AD}$ is quite comparable with Shapiro-Wilk test, and has a high power for samples equal to or greater than 30 individuals. Normality tests were performed with a confidence level of $99 \%$ (significance level $(\alpha)$ of $1 \%$ ) and the lower the p-value, the lower the consistency between the data and the null hypothesis, which corresponds to the Normal distribution. As the data did not present a normal distribution, the Spearman coefficient $\rho$ was used, which is a bivariate correlation procedure that does not require the relationship between the variables to be linear, to measure the strength of the association between the ordinal variables and uses the order of observations, instead of the observed value, only 
(Pestana and Velosa, 2006).

\subsection{Interviews design, sample and data analysis}

Lastly, in the third stage, after identifying 10 most important measures, we conducted eleven semi-structured interviews in the Portuguese language with academics. Each interview lasted around half hour. We applied a questionnaire with five professors, which have at least master's degrees, in Fluminense Federal University, Niterói, Brazil on November 22th and six managers from Tecgraf Institute on November 24th 2017 in the Pontifical Catholic University of Rio de Janeiro, Brazil. Given that all the respondents were familiar with Lean Six Sigma methodology or have already worked at least once in a project involving Lean, Six Sigma, LSS or Green techniques, during face-to-face meetings with them, the authors didn't need to explain these methodologies and their concepts. The experts were asked to fill out the questionnaire using a 3-point scale (i.e., $0=$ no influence, $+=$ moderate,$++=$ strong) to indicate the influence of each operational improvement programme to handle the key sustainable measures in their respective organization.

After collecting questionnaire data from all the respondents, we calculated the mode of the respondents' opinions in order to reach a consensus. In addition, as Caffieri et al. (2017) a manual content analysis - systematic classification process of coding and identifying themes or patterns - was used to analyze the interviews. It enabled the researchers with the opportunity of direct and personal interaction with professionals with ample industry and academic experience in order to make inferences about the reasons of the relationships between the key sustainable performance measures and some operational improvement programmes, and for identifying how organizations may achieve better sustainable performance in implementing programmes and controlling these measures.

\section{Results and Discussion}

\subsection{Survey results}

Concerning the degree of importance of measuring organizational sustainability, Table 2 shows that, from weighted frequency analysis, sustainable measures which are considered more important by the interest group's perception are: Cost performance (M1), Environmental protection (M5), Supplier relations (M7), Corporate reputation (M8), Quality management (M10), Customer satisfaction (M12), Human capital 
development (M22), Energy conservation (M24), Reduction in amount of energy use (M27) and Reduction in amount of resource use (M30).

Table 2. Degree of the importance of sustainable performance measures 


\begin{tabular}{|c|c|c|c|c|c|c|}
\hline Suatainable Performance Measures & $\begin{array}{l}\text { Very Low } \\
\text { (1) }\end{array}$ & $\begin{array}{l}\text { Low } \\
\text { (2) }\end{array}$ & $\begin{array}{c}\text { Medium } \\
\text { (3) }\end{array}$ & $\begin{array}{l}\text { High } \\
\text { (4) }\end{array}$ & $\begin{array}{l}\text { Very high } \\
\text { (5) }\end{array}$ & $\begin{array}{l}\text { Weighted } \\
\text { frequency }\end{array}$ \\
\hline Corporate reputation (M8) & $7 \%$ & $10 \%$ & $10 \%$ & $27 \%$ & $47 \%$ & $96.7 \%$ \\
\hline Environmental protection (M5) & $13 \%$ & $7 \%$ & $7 \%$ & $33 \%$ & $40 \%$ & $80.0 \%$ \\
\hline Customer satisfaction (M12) & $7 \%$ & $13 \%$ & $17 \%$ & $20 \%$ & $43 \%$ & $80.0 \%$ \\
\hline Quality management (M10) & $3 \%$ & $13 \%$ & $20 \%$ & $27 \%$ & $37 \%$ & $80.0 \%$ \\
\hline $\begin{array}{l}\text { Reduction in amount of energy use } \\
\text { (M.27) }\end{array}$ & $10 \%$ & $10 \%$ & $17 \%$ & $20 \%$ & $43 \%$ & $76.7 \%$ \\
\hline Cost performance (Ml) & $7 \%$ & $10 \%$ & $20 \%$ & $33 \%$ & $30 \%$ & $70.0 \%$ \\
\hline Supplier relations (M7) & $10 \%$ & $10 \%$ & $20 \%$ & $20 \%$ & $40 \%$ & $70.0 \%$ \\
\hline Energy conservation (M24) & $10 \%$ & $13 \%$ & $20 \%$ & $13 \%$ & $43 \%$ & $66.7 \%$ \\
\hline $\begin{array}{l}\text { Reduction in amount of resource use } \\
\text { (M30) }\end{array}$ & $10 \%$ & $10 \%$ & $30 \%$ & $13 \%$ & $37 \%$ & $56.7 \%$ \\
\hline Human capital development (M22) & $7 \%$ & $10 \%$ & $30 \%$ & $30 \%$ & $23 \%$ & $53.3 \%$ \\
\hline Investor Relations (M17) & $20 \%$ & $10 \%$ & $13 \%$ & $13 \%$ & $43 \%$ & $50.0 \%$ \\
\hline Code of conduct (M19) & $10 \%$ & $13 \%$ & $17 \%$ & $37 \%$ & $23 \%$ & $50.0 \%$ \\
\hline Corporate Governance (M.20) & $7 \%$ & $7 \%$ & $43 \%$ & $20 \%$ & $23 \%$ & $46.7 \%$ \\
\hline Waste management (M29) & $17 \%$ & $7 \%$ & $17 \%$ & $37 \%$ & $23 \%$ & $43.3 \%$ \\
\hline $\begin{array}{l}\text { Environmental and social } \\
\text { performance (M2) }\end{array}$ & $13 \%$ & $7 \%$ & $30 \%$ & $27 \%$ & $23 \%$ & $40.0 \%$ \\
\hline Social benefits, medical-legal (M11) & $17 \%$ & $3 \%$ & $20 \%$ & $43 \%$ & $17 \%$ & $40.0 \%$ \\
\hline Employee satisfaction (M6) & $13 \%$ & $10 \%$ & $20 \%$ & $37 \%$ & $20 \%$ & $40.0 \%$ \\
\hline Transparency in information (M14) & $17 \%$ & $10 \%$ & $23 \%$ & $17 \%$ & $33 \%$ & $40.0 \%$ \\
\hline $\begin{array}{l}\text { Representation and dialogue with } \\
\text { employees (M18) }\end{array}$ & $13 \%$ & $10 \%$ & $27 \%$ & $27 \%$ & $23 \%$ & $36.7 \%$ \\
\hline $\begin{array}{l}\text { Sustainable working condition } \\
\text { (MD25) }\end{array}$ & $7 \%$ & $7 \%$ & $40 \%$ & $37 \%$ & $10 \%$ & $36.7 \%$ \\
\hline Environmental Policy (M16) & $20 \%$ & $10 \%$ & $13 \%$ & $33 \%$ & $23 \%$ & $30.0 \%$ \\
\hline $\begin{array}{l}\text { Intra-firm collaborative capabilities } \\
\text { (M(4) }\end{array}$ & $3 \%$ & $23 \%$ & $37 \%$ & $20 \%$ & $17 \%$ & $23.3 \%$ \\
\hline Environmental logiatics policy (M9) & $17 \%$ & $13 \%$ & $20 \%$ & $30 \%$ & $20 \%$ & $23.3 \%$ \\
\hline Support of social setting (M.23) & $13 \%$ & $13 \%$ & $27 \%$ & $33 \%$ & $13 \%$ & $20.0 \%$ \\
\hline $\begin{array}{l}\text { Inter-firm collaborative capabilities } \\
\text { (MI3) }\end{array}$ & $3 \%$ & $27 \%$ & $30 \%$ & $30 \%$ & $10 \%$ & $16.7 \%$ \\
\hline Labor practice indicators (M21) & $10 \%$ & $17 \%$ & $27 \%$ & $40 \%$ & $7 \%$ & $16.7 \%$ \\
\hline $\begin{array}{l}\text { Sources of recyclable raw material } \\
\text { (Mi31) }\end{array}$ & $10 \%$ & $23 \%$ & $20 \%$ & $33 \%$ & $13 \%$ & $16.7 \%$ \\
\hline Green Marketing (M15) & $27 \%$ & $7 \%$ & $20 \%$ & $27 \%$ & $20 \%$ & $6.7 \%$ \\
\hline Carbon foot print reduction (M26) & $27 \%$ & $10 \%$ & $17 \%$ & $23 \%$ & $23 \%$ & $6.7 \%$ \\
\hline Reduction of air pollution (M.28) & $27 \%$ & $7 \%$ & $20 \%$ & $27 \%$ & $20 \%$ & $6.7 \%$ \\
\hline $\begin{array}{l}\text { Balancing professional and family } \\
\text { life (M13) }\end{array}$ & $13 \%$ & $23 \%$ & $23 \%$ & $30 \%$ & $10 \%$ & $0.0 \%$ \\
\hline Weights & -2 & -1 & 0 & 1 & 2 & \\
\hline
\end{tabular}

Considering the results described in Table 2, we identified the importance ranking of the measures as: $\mathrm{M} 8>\mathrm{M} 5=\mathrm{M} 12=\mathrm{M} 10>\mathrm{M} 27>\mathrm{M} 1>\mathrm{M} 7>\mathrm{M} 24>\mathrm{M} 30>\mathrm{M} 22$ based on their WF. Thus, these measures are considered the key sustainable performance measures. 
Hence, environmental, social, economic, technical and governance measures were all considered as the most important. In that manner, it is perceived that as corporate sustainability is a multidimensional concept all dimensions must be evaluated in an integrated way (Caiado et al. 2017). It is up to the organization to measure its performance in relation to the most important measures considered in order to invest the right resources, avoiding waste and promoting integrated management for long-term sustainable development and to create a performance measurement system which in turn must cover these ten measures, aiming to transition to sustainable development.

The internal reliability and non-parametric tests results of normality tests are observed on Table 3.

Table 3. Results of non-parametric tests and Cronbach's alpha 


\begin{tabular}{|c|c|c|c|c|c|}
\hline \multirow{2}{*}{ Measures } & \multicolumn{2}{|c|}{$\begin{array}{c}\text { Lilliefors (Kolmogorov-Smirnov) } \\
\text { normality test }\end{array}$} & \multicolumn{2}{|c|}{$\begin{array}{l}\text { Anderson-Darling } \\
\text { normality test }\end{array}$} & \multirow{2}{*}{$\begin{array}{l}\text { Cronbach's } \\
\text { alphas }\end{array}$} \\
\hline & statistic (D) & p-value & statistic (A) & p-value & \\
\hline M1 & 0.2314 & 0.0003 & 1.4132 & 0.0009 & 0.9683 \\
\hline $\mathrm{M} 2$ & 0.1794 & 0.0148 & 1.2033 & 0.0032 & 0.9676 \\
\hline M3 & 0.1856 & 0.0098 & 1.2251 & 0.0028 & 0.9686 \\
\hline M4 & 0.2170 & 0.0009 & 1.21 & 0.0031 & 0.9681 \\
\hline M5 & 0.2901 & $6,39 \mathrm{E}-04$ & 2.5863 & $1,07 \mathrm{E}-03$ & 0.9677 \\
\hline M6 & 0.2441 & $8,26 \mathrm{E}-02$ & 1.3973 & 0.0010 & 0.968 \\
\hline M7 & 0.2289 & 0.0003 & 1.7541 & 0.0001 & 0.9678 \\
\hline M8 & 0.2583 & $2,06 \mathrm{E}-02$ & 2.5052 & $1,71 \mathrm{E}-03$ & 0.9686 \\
\hline M9 & 0.2105 & 0.0015 & 1.1611 & 0.0041 & 0.9676 \\
\hline M10 & 0.2108 & 0.0015 & 1.5915 & 0.0003 & 0.9679 \\
\hline M1l & 0.2775 & $2,69 \mathrm{E}-03$ & 2.0456 & $2,43 \mathrm{E}-02$ & 0.9675 \\
\hline $\mathrm{M} 12$ & 0.2510 & $4,24 E-02$ & 1.9975 & $3,21 \mathrm{E}-02$ & 0.9685 \\
\hline M13 & 0.1916 & 0.0065 & 1.0253 & 0.0091 & 0.9682 \\
\hline M14 & 0.1941 & 0.0054 & 1.4343 & 0.0008 & 0.9675 \\
\hline M15 & 0.1988 & 0.0038 & 1.4919 & 0.0006 & 0.9678 \\
\hline M16 & 0.2502 & $4,60 \mathrm{E}-02$ & 1.6232 & 0.0003 & 0.9675 \\
\hline M17 & 0.2571 & $2,33 \mathrm{E}-02$ & 2.2914 & $5,88 \mathrm{E}-03$ & 0.9693 \\
\hline M18 & 0.1836 & 0.0113 & 1.1079 & 0.0056 & 0.9674 \\
\hline M19 & 0.2519 & $3,86 \mathrm{E}-02$ & 1.4001 & 0.0010 & 0.9680 \\
\hline $\mathrm{M} 20$ & 0.2259 & 0.0004 & 1.5064 & 0.0005 & 0.9682 \\
\hline M21 & 0.2389 & 0.0001 & 1.4925 & 0.0006 & 0.9685 \\
\hline $\mathrm{M} 22$ & 0.1887 & 0.0079 & 1.1317 & 0.0049 & 0.9682 \\
\hline $\mathrm{M} 23$ & 0.2067 & 0.0021 & 1.1355 & 0.0047 & 0.9679 \\
\hline M.24 & 0.2590 & $1,90 \mathrm{E}-02$ & 1.9714 & $3,74 \mathrm{E}-02$ & 0.9676 \\
\hline M.25 & 0.2235 & 0.0005 & 1.6021 & 0.0003 & 0.9675 \\
\hline M26 & 0.1928 & 0.0059 & 1.4669 & 0.0007 & 0.9688 \\
\hline $\mathrm{M} 27$ & 0.2473 & $6,10 \mathrm{E}-02$ & 2.0377 & $2,55 \mathrm{E}-02$ & 0.9682 \\
\hline M28 & 0.1988 & 0.0038 & 1.4919 & 0.0006 & 0.9681 \\
\hline M.29 & 0.2591 & $1,88 \mathrm{E}-02$ & 1.6946 & 0.0002 & 0.9683 \\
\hline M30 & 0.2213 & 0.0006 & 1.5745 & 0.0004 & 0.9675 \\
\hline M31 & 0.2169 & 0.0009 & 1.1285 & 0.0049 & 0.9678 \\
\hline
\end{tabular}

The value of Cronbach's alpha of the entire set was 0.969, which shows high reliability (Hair et al. 2009). The Cronbach $\alpha$ coefficients range from 0.9674 to 0.9693 . The values exceed the recommended cut off value of 0.6 , which means that a group of items is homogeneous or internally consistent and the reliability of each variable was confirmed (Hair et al. 2009; Sureeyatanapas et al. 2015). By normality test it was noticed that there was no statistical significance between the LF and AD values of the variables of the test and the comparison of the p-value measures less than 0.01 it was possible to verify that the data is not normally distributed.

As the data did not present a normal distribution, we used Spearman's correlation 
between measurements (Table 4), which is the most appropriate for non-parametric data, because the coefficient measures the intensity of the relationship between variables and is suitable for both continuous and discrete variables including ordinal variables (Rashidi and Farzipoor Saen 2015).

Table 4. Spearman correlation between the key sustainable performance measures

\begin{tabular}{|c|c|c|c|c|c|c|c|c|c|c|}
\hline & M1 & M5 & M7 & Ms & M10 & $M 12$ & $M 22$ & $M 24$ & $M 27$ & M30 \\
\hline Cosst performance (M1) & 1 & & & & & & & & & \\
\hline Environmental protection (M5) & 0.3185 & 1 & & & & & & & & \\
\hline Supplier relations (M7) & 0.4304 & 0.4631 & 1 & & & & & & & \\
\hline Corporate reputation (M8) & $0.5347^{*}$ & 0.4585 & 0.4194 & 1 & & & & & & \\
\hline Quality management (M10) & 0.5017 & 0.3456 & $0.6441^{*}$ & $0.5561^{*}$ & 1 & & & & & \\
\hline Customer satisfaction (M12) & $0.5183^{*}$ & 0.3416 & $0.5692^{*}$ & $0.5733^{*}$ & $0.7382 *$ & 1 & & & & \\
\hline Human capital develonment (M22) & 0.2068 & 0.4034 & $0.6389^{*}$ & 0.2744 & $0.5311^{*}$ & 0.2672 & 1 & & & \\
\hline $\begin{array}{l}\text { Energy conservation (M24) } \\
\text { Reduction in amount of energy use }\end{array}$ & 0.4281 & 0.4324 & 0.4612 & 0.2433 & $0.5031^{*}$ & 0.4443 & $0.6352^{*}$ & 1 & & \\
\hline $\begin{array}{l}\text { (M27) } \\
\text { Reduction in amount of resource }\end{array}$ & 0.3563 & 0.3862 & 0.4113 & 0.1788 & 0.4478 & $0.4927^{*}$ & $0.5056^{*}$ & $0.9205^{*}$ & 1 & \\
\hline used (M30) & $0.5114^{*}$ & $0.4853^{*}$ & 0.5472 & 0.1961 & 0.3920 & 0.4543 & $0.5675^{*}$ & $0.7576^{*}$ & $0.7842^{*}$ & 1 \\
\hline
\end{tabular}

Based on the correlation between the key measures (Table 4), it can be seen that there is moderate and positive correlation between the following measures: M1 and M8 $(\rho=0.5347) ;$ M1 and M10 $(\rho=0.5017) ;$ M1 and M12 $(\rho=0.5183) ;$ M7 and M10 $(\rho=$ 0.6441); M7 and M12 (0.5692); M7 and M22 ( $\rho=0.6389) ;$ M10 and M22 ( $\rho=0.5311)$; M10 and M24 $(\rho=0.5031)$; M22 and M24 $(\rho=0.6352)$; M22 and M27 $(\rho=0.5056)$; M22 and M30 $(\rho=0.5675)$. These results imply that the hypothesis $\mathrm{H}_{1}$ was corroborated, since energy conservation (M24) - an environmental measure - and human capital development (M22) - a social measure - are both positively associated with quality management (M10).

One possible case for this would be in organizations that invest in quality management, through continuous improvement methodologies such as the Plan-DoCheck-Act (PDCA) used in LM, or the DMAIC cycle along with Six Sigma statistical tools, which usually improve efficiency in the use of natural resources, and reduce energy expenditure and environmental impacts throughout their processes. In addition to this, it is common that organizations that implement operational improvement programs such as the LSS methodology, seeking to increase quality management, also have an increased participation of all human capital in a never-ending process, since the lean philosophy seeks to engage all employees at a transformational change.

Besides that, these results indicated that the hypothesis $\mathrm{H}_{2}$ was confirmed, since there is positive correlation between supplier relations (M7) and customer satisfaction (M12). A possible reason for that is: the agility of the supply chain depends on customer 
satisfaction, as well as improvement of quality management. Thus, companies have been forced to rethink how they manage their supply chain operations and the "lean supply chain" - strategy based on cost reduction and flexibility, focused on processes improvements - (Carvalho, Duarte, and Cruz Machado 2011) linked to agility becomes paramount to fulfil customers' needs.

Also, there is a strong association between the variables: M10 and M12 ( $\rho=$ 0.7382); M24 and M27 ( $\rho=0.9005)$; M24 and M30 ( $\rho=0.7576)$; M27 and M30 ( $\rho=$ 0.7842). It indicates a conclusion that seems obvious: the consumption of resources and energy is directly bonded with the conservation of energy. Thus, the implementation of methodologies like GLSS could be a good solution to contain the waste of resources and reduce energy expenditure through more efficient processes.

Finally, there is a weak correlation between M12 and M22 $(\rho=0.2672)$; M8 and M27 $(\rho=0.1788)$; M8 and M30 $(\rho=0.1961)$; M1 and M22 $(\rho=0.2068)$. These results portray two conclusions. First, that human capital development (such as training, development and empowerment) has little influence on cost performance and customer satisfaction. One possible reason for this would be the low concern with staff and the social issue for greater technical and financial performance.

In addition, it is noted that there is a weak relationship between corporate reputation and the reduction of the amount of energy and resources. This leads to the conclusion that, in the evaluated organizations, environmental issues have little influence on reputation, which seems to be more impacted by customer satisfaction and quality management.

\subsection{Interview results}

Based on the interviews, the academics were asked to indicate some relations between the sustainable performance measures and the operational improvement programmes. Table 5 summarizes the intensity of impact of these programmes to handle the key measures that are acting as driver forces for adoption of sustainable development.

Table 5. Relations between operational improvement programmes and key sustainable performance measures 


\begin{tabular}{|c|c|c|c|c|c|c|}
\hline \multirow[b]{2}{*}{ Dimension } & \multirow[b]{2}{*}{ Key sustainable performance measures } & \multicolumn{5}{|c|}{ Operational improvement programmes } \\
\hline & & Lean & $\begin{array}{c}\text { Six } \\
\text { Sigma }\end{array}$ & LSS & $\begin{array}{l}\text { Green } \\
\text { Lean }\end{array}$ & GLSS \\
\hline Esconomic & Cosst performance & + & + & ++ & + & ++ \\
\hline \multirow{4}{*}{ Environmental } & Environmental protection. & + & 0 & + & ++ & ++ \\
\hline & Energy conservation & + & 0 & + & ++ & ++ \\
\hline & Reduction in amount of energy use & + & 0 & + & ++ & ++ \\
\hline & Reduction in amount of resource use & + & 0 & + & ++ & ++ \\
\hline Goxernance & Corporate reputation & 0 & + & + & 0 & + \\
\hline \multirow{2}{*}{ Social } & Supplier relations & + & 0 & 0 & ++ & ++ \\
\hline & Human capital development & + & 0 & + & + & + \\
\hline \multirow{2}{*}{ Technical } & Qualitx management & + & + & ++ & ++ & ++ \\
\hline & Customer satisfaction & + & + & ++ & ++ & ++ \\
\hline
\end{tabular}

As Table 5, those programmes can have a more important, a strong positive impact on bottom line performance when implemented together because the combination of Lean / Six Sigma and Green could generate better results rather than separately (Miller et al. 2010).

According to content analysis, among all the key sustainable performance measures, quality management, cost performance, and corporate reputation were considered the most important measures to operational improvement. In addition, environmental protection, supplier relations, and cost performance were considered the most important measures for TBL sustainability view. Besides that, from the operational improvement programmes perspective, quality management was considered the most important for Six Sigma, cost performance was considered the most important for LM, environmental protection was considered the most important for Green, Supplier relations was considered the most important for Lean Green, and corporate reputation was considered the most important for GLSS.

Hence, quality management (technical issue), corporate reputation (governance issue), environmental protection (environmental issue), supplier relations (social issue) and cost performance (economic issue) are the most important factors. Thus, these key sustainable measures are highlighted in grey color in Table 5, as they are considered essential for improvement of operational and sustainability performance.

As noticed in this analysis, the Lean/Six Sigma programmes usually has no influence over some measures associated to governance and social dimensions. However, as Singh et al. (2007), the TBL needs to add those dimensions in order to improve the sustainable management in a complete way. Because of that, there is a need to integrate 
operational and financial methods with green practices, corporate social responsibility and governance to achieve sustainable development in a global perspective.

\section{Guidelines to achieve sustainability through alignment of key sustainable measures and operational improvement programmes}

\subsection{Enviromental Protection}

Lean can contribute to decrease in pollution and thereby combat global warming through the development of an efficiency metric that can help to decrease the environmental impacts (Chugani et al. 2017). To achieve the environmental protection some important actions are necessary:

- to engage employees, empowering and motivating them in order to increase their participation and to propose collaborative initiatives through cultural changes to build stronger and more sustainable-oriented organizations. The internal organizational factors are the main promoters of the sustainable environment in organizations, and therefore, kaizen events, workshops, talks and organizational learning practices in sustainability are of interest in order to perpetuate this cultural change, a challenging obstacle which is being gradually overcome, as the research indicates;

- to improve the use of natural resources through a higher productivity and the support from top management, as sustainability must be operationalized in a topdown way, starting with high management and working towards lower levels, due to the close relation of sustainability with strategic planning;

- to use LM methods as total productive maintenance (TPM) to improve reliability and decrease environmental impacts and cellular manufacturing in order to facilitate the focus on sustainability at the operational level;

- to adapt value stream mapping (VSM) to asses energy and resource consumption;

- to use Lean methods associated with Green approaches as cleaner production, ecoefficiency and life cycle analysis (LCA). In fact, Lean and Green actions could be and could provide a method for companies to develop a tool to measure both productivity and environmental performance based on qualitative and quantitative analysis (Verrier et al. 2014);

- to adopt Green and Lean methods as 5S (housekeeping) process that allows a 
visual management for reducing inefficiency, the lot size and the stock reduction and $3 \mathrm{R}$ (reduction, reuse and recycle) for reduction of redundant and unnecessary materials and reuse of materials throughout the value stream;

- to create new and smarter technologies, which can contribute to the alignment of Lean/Six Sigma and sustainable operations and may suggest better choices in the use of energy and materials;

\subsection{Cost Performance}

Achieving the improvement of cost performance requires a holistic and targeted strategy for change by means of the following actions:

- to promote cost reduction through improvement/kaizen circles and effective counter measures to the root causes of previously identified problems;

- to achieve a significant reduction in amount of resources and energy use through the integration of Green, Lean and Six Sigma methodologies seeking efficiency and effectiveness.

- to support the human resources and practices with sustainable issues and to promote a clear policy and training for all employees in order to bring an integrated consensus about the definitions of Lean and sustainability, enhancing their skills and providing know-how;

\subsection{Supplier relations}

The improvement of relations with suppliers requires a clear communication which is associated to the following actions:

- to integrate the supply chain in order to decrease resource waste and loss of efficiency in processes, by making complete use of organizational support, social capital practices and the government participation towards the implementation of green supply chain management;

- to develop performance measurement systems (PMSs) that integrate TBL metrics with other governance and technical metrics within the entire company and across the supply chain;

- to deploy a proactive Green Supply Chain Management (GSCM) through green purchase, green design, product recovery and client and supplier collaboration (Lin 2013); 
- to select suppliers based on sustainability criteria and to establish vendor development/collaboration.

\subsection{Corporate reputation}

Achieving the corporate reputation requires the improvement of public image and corporate governance, seeking the following actions:

- a voluntary promotion of information on sustainable performance by using Six Sigma metrics and tools to show transparency to stakeholders and to better control emissions of pollutants and profit margins. It is important to conceive a sustainable system which produces periodic information on the facilities' performance; continuously measures performance to track progress in sustainability; updates and improves company performance through external benchmarking; establishes communication channels with stakeholders, in a way that the demands of society, external levers, and management practices are met in the same way and encourages participation of stakeholders in the decision making process;

- a strong committed leadership and dedication of the employees, resources of the entire firm and senior management support;

- to create a Green innovative product design and sustainable services through a transformational change involving jointly concepts of lean manufacturing, Six Sigma and sustainability;

- to promote environmental care with the adoption of standards or guides as ISO 14000 in order to pursue ethical relations and to comply with regulations. From there, organizations can standardize their professional practices concerning verified performance.

\subsection{Quality Management}

Improving quality management and practices is associated to improve environmental performance and requires the following actions:

- to apply Lean concepts as zero defect manufacturing led to durable products, quick changes and delivery, Just-in-Time to produce exactly what the customer wants, Kanban for creating a pulled flow and continuous improvement of products and services to optimize time, people, space and machines; 
- to stablish a structured solving methodology as DMAIC with the performance measures to asses customer returns through Six Sigma tools to increase loyalty;

- to integrate Lean and Six Sigma methodologies to assist in identifying and eliminate waste, with no delay, at fair price and minimum waste;

\section{Conclusions}

This research provides various managerial insights that are not only limited to the academic level but also shed light on managerial and policy makers' perspectives. Each perspective's implications are well detailed below.

\subsection{Theoretical implications}

This paper has fulfilled the gap in the literature by proposing guidelines for better measurement of sustainable performance through the effective alignment of triple bottom line objectives and operational improvement programmes in Brazilian organizations, given a glimpse of the current situation of corporate sustainability and indicating fertile areas for further academic inquiry.

The study results reveal that very little attention is paid to governance and societal concerns in the operational improvement programmes context, and emphasizes some key areas where the academic studies still need to upgrade and to delve more deeply. This study act as pioneering work in terms of an exploratory in-depth investigation in order to align Lean, Six Sigma and Green methodologies within corporate sustainable performance measures with a specific geographical perspective.

\subsection{Practical implications}

The results of this research offers some managerial implications for professionals who want to integrate operational improvement programmes such as Lean/Six Sigma into sustainable performance measures. First, the findings show that it is essential to use sustainable performance measurement systems in order to respond to external and internal levers. Second, it is the responsibility of organizations to focus their efforts on environmental protection, corporate reputation, quality management, supplier relations and cost performance, as they were evaluated as essential performance measures for operational and sustainability improvement, considering a holistic view of the operational improvement programs and the triple bottom line in an integrated way. Third, our 
guidelines assists industrial managers to focus on the essential operational improvement programmes that will further improve their chances of successful implementation of sustainable manufacturing. Recent business environments force managers to concentrate on many factors, and they are urged to make fine decisions every time. Hence, it is difficult for industrial managers to select and work around the most important performance measures. With this concern, this study supports their decision in terms of the key sustainable performance measures with proper programmes.

The use of PMS may enable managers and leaders to control their own performance, evaluate the team's performance effectively and efficiently, and possibly serve as benchmarking for organizations and aid them in the development of future operations and strategies.

\subsection{Political implications}

Besides that, to achieve a better corporate sustainable performance in products and services, transformational challenges such as cultural barriers, complex organizational designs and organizational structures, complex processes, and technology systems should be overcame and government policies should determine rules and restrictions to put the environmental and social responsibilities in a higher priority. Furthermore, incentive policies may encourage the organizations to invest more on sustainability improvement and optimization which benefit the stakeholders. At this point, this study assists governments and decision making organizations to revisit the policies with a focus towards sustainability. As they have the major roles in terms of investment, training, legislation and management, planning, operationalizing and controlling the sustainable performance, it is time for those policy makers to accept the importance of implementing sustainable manufacturing practices aligned with operational improvement programmes.

\subsection{Limitations and suggestions for further work}

Finally, as a sequence to this work, aside from the possibility of counting on a survey with a larger sample composed by more organizations and replicating this instrument in other circumstances, we suggest the continuity of the research on this theme can lead to new ways of better understanding the correlation results between the TBL measures and operational measures of corporate sustainability and investigating the reasons for the relevance of one measure or indicator over others in order to enhance the quality and robustness of the corporate sustainable performance. 
More research should therefore focus on social and governance concerns and companies should achieve sustainability not only by implementing practices such as LM, Six Sigma or Lean Six Sigma, but also by improving their key sustainable performance measures. The identification and selection of the appropriate measures must be constantly adapted and changed according to the objectives of the organization. Furthermore, it is essential that the measures reflect the concerns of all stakeholders. Aside from the objective behind these measures, the type of company must also be considered, as well as the sector studied, the size of the company, the proximity to markets sensitive to environmental issues, external regulation, and to the organization's corporate culture (Fiksel et al. 1999).

\section{References}

Adams, A. C., S. Muir, and Z. Hoque 2014. 'Measurement of sustainability performance in the public sector.' Sustainability Accounting, Management and Policy Journal 5: 46-67. doi:10.1108/SAMPJ-04-2012-0018

Ahuja, R., A. Sawhney, and M. Arif. 2016. 'Driving Lean and Green Project Outcomes Using BIM: A Qualitative Comparative Analysis'. International Journal of Sustainable Built Environment, no. November. The Gulf Organisation for Research and Development. doi:10.1016/j.ijsbe.2016.10.006.

Caffieri, J. J., Love, P. E. D., Whyte, A., and Ahiaga-dagbui, D. D. 2017. 'Planning for Production in Construction: Controlling Costs in Major Capital Projects'. Production Planning \& Control, $29 \quad$ (1): 41-50. doi:10.1080/09537287.2017.1376258.

Caiado, R. G. G., R. de F. Dias, L. V. Mattos, O. L. G. Quelhas, and W. Leal Filho. 2017. 'Towards Sustainable Development through the Perspective of Eco-Efficiency - A Systematic Literature Review'. Journal of Cleaner Production 165: 890-904. doi:10.1016/j.jclepro.2017.07.166.

Caiado, R. G. G., G. B. A. Lima, L. O. Gavião, O. L. G. Quelhas, and F. F. Paschoalino. 2017. 'Sustainability Analysis in Electrical Energy Companies by Similarity Technique to Ideal Solution'. IEEE Latin America Transactions 15 (4): 675-81.

Caiado, R. G. G., O. L. G. Quelhas, D. L. M. Nascimento, R. Anholon, and W. Leal Filho. 2017. 'Measurement of Sustainability Performance in Brazilian Organizations Measurement of Sustainability Performance in Brazilian Organizations'. International Journal of Sustainable Development \& World Ecology 0 (0). Taylor \& Francis: 1-15. doi:10.1080/13504509.2017.1406875.

Calder, B. J., L. W. Phillips, and A. M. Tybout. 1981. 'Designing Research for Application.' Journal of Consumer Research. 8: 197-207.

Campos, L. M. S., and D. A. Vazquez-Brust. 2016. 'Lean and Green Synergies in Supply Chain Management'. Supply Chain Management: An International Journal 21 (5): 627-41. doi:10.1108/SCM-03-2016-0101.

Camuffo, A., and F. De Stefano. 2017. 'Safety Reloaded: Lean Operations and High 
Involvement Work Practices for Sustainable Workplaces'. Journal of Business Ethics. Springer Netherlands, 245-59. doi:10.1007/s10551-015-2590-8.

Carvalho, H., S. Duarte, and V. Cruz Machado. 2011. 'Lean, Agile, Resilient and Green: Divergencies and Synergies'. International Journal of Lean Six Sigma 2 (2): 15179. doi:10.1108/20401461111135037.

Cherrafi, A., S. Elfezazi, A. Chiarini, A. Mokhlis, and K. Benhida. 2016. 'The Integration of Lean Manufacturing, Six Sigma and Sustainability: A Literature Review and Future Research Directions for Developing a Specific Model.' Journal of Cleaner Production 139: 828-46. doi:10.1016/j.jclepro.2016.08.101.

Cherrafi, A., S. Elfezazi, K. Govindan, J. A. Garza-Reyes, K. Benhida, and A. Mokhlis. 2017. 'A Framework for the Integration of Green and Lean Six Sigma for Superior Sustainability Performance.' International Journal of Production Research, no. March. Taylor \& Francis: 1-35. doi:10.1080/00207543.2016.1266406.

Chiarini, A. 2014. 'Sustainable Manufacturing-Greening Processes Using Specific Lean Production Tools: An Empirical Observation from European Motorcycle Component Manufacturers.' Journal of Cleaner Production 85: 226-33. doi:10.1016/j.jclepro.2014.07.080.

Chugani, N., V. Kumar, J. A. Garza-Reyes, L. Rocha-Lona, and A. Upadhyay. 2017. 'Investigating the Green Impact of Lean, Six Sigma, and Lean Six Sigma: A Systematic Literature Review.' International Journal of Lean Six Sigma. Vol. 8. doi:10.1108/IJLSS-11-2015-0043.

Ciliberti, F., P. Pontrandolfo, and B. Scozzi. 2008. Logistics social responsibility: standard adoption and practices in Italian companies. International Journal of Production Economics 113: 88-106.

Eisenhardt, K. M. 1989. 'Building theories from case study research.' Academy of Management Review 14(4): 532-550.

Elkington, J. 1998. Cannibals with Forks - The Triple Bottom Line of 21st Century Business, Grabiola Island: New Society Publishers.

Epstein, M.J. and M.J. Roy. 2001. 'Sustainability in Action: Identifying and Measuring the Key Performance Drivers.' Long Range Planning. 34: 585-604.

Etzion, D., 2007. Research on organization sand the natural environment,1992- present: a review. Journal of Management 33(4): 637-664.

Fercoq, A., S. Lamouri, and V. Carbone. 2016. 'Lean/Green Integration Focused on Waste Reduction Techniques'. Journal of Cleaner Production 137: 567-78. doi:10.1016/j.jclepro.2016.07.107.

Fiksel, J.; Mcdaniel, J.; Mendenhall, C., 1999. Measuring Progress towards Sustainability Principles. Process and Best Practices. Ohio: Battelle Memorial Institute.

Forza, C., 2012. Survey Research in Operations Management: a Process-based Perspective. International Journal of Operations \& Production Management, Bradford, 22 (2), 152-194.

Fu, X., M. Guo, and N. Zhanwen. 2017. 'Applying the Green Embedded Lean Production Model in Developing Countries: A Case Study of China'. Environmental Development 24: 22-35. doi:10.1016/j.envdev.2017.02.004.

Gandhi, N. S., S. J. Thanki, and Jitesh J Thakkar. 2018. 'Ranking of Drivers for Integrated Lean-Green Manufacturing for Indian Manufacturing SMEs'. Journal of Cleaner 
Production 171: 675-89. doi:10.1016/j.jclepro.2017.10.041.

Garza-Reyes, J. A. 2015. 'Green Lean and the Need for Six Sigma'. International Journal of Lean Six Sigma 6 (3): 226-48. doi:10.1108/IJLSS-04-2014-0010.

Garza-reyes, J. A., B. Villarreal, and V. Kumar. 2017. 'Lean and Green in the Transport and Logistics Sector - A Case Study of Simultaneous Deployment'. Production Planning \& Control 27 (2016): 1221-32.

George M.L. 2002. "Lean Six Sigma: Combining Six Sigma Quality with Lean Production Speed”, McGraw Hill Professional, ISBN: 978-0071385213

Godinho Filho, M., G. M. D. Ganga, and A. Gunasekaran. 2016. 'Lean Manufacturing in Brazilian Small and Medium Enterprises: Implementation and Effect on Performance'. International Journal of Production Research 7543 (June): 1-23. doi:10.1080/00207543.2016.1201606.

Golini, R., A. Longoni, and R. Cagliano. 2014. 'Developing sustainability in global manufacturing networks: The role of site competence on sustainability performance.' International Journal of Production Economics 147: 448-459.

Govindan, K., R. Khodaverdi, and A. Jafarian. 2013. 'A fuzzy multi criteria approach for measuring sustainability performance of a supplier based on triple bottom line approach.' Journal of Cleaner Production 47: 345-354.

Hair Jr., J., W. Black, B. Babin, and R. Anderson, 2009. Multivariate Data Analysis, 7th edition. Prentice-Hall, Upper Saddle River, NJ.

Helleno, A. L., A. J. I. de Moraes, and A. T. Simon. 2016. 'Integrating Sustainability Indicators and Lean Manufacturing to Assess Manufacturing Processes: Application Case Studies in Brazilian Industry.' Journal of Cleaner Production. doi:10.1016/j.jclepro.2016.12.072.

Hines, W. W., and D. C. Montgomery. 1990. Probability and Statistics in Engineering and Management Science. 3rd ed. New York: Wiley

Hourneaux Jr., F., H. A. Hrdlicka, C. M. Gomes, and I. Kruglianskasd. 2014. 'The use of environmental performance indicators and size effect: A study of industrial companies.' Ecological Indicators 36: 205- 212.

Kocmanová, A., M. P. Dočekalová, S. Škapa, and L. Smolíková. 2016. 'Measuring Corporate Sustainability and Environmental, Social, and Corporate Governance Value Added.' Sustainability 8(9), 945. doi:10.3390/su8090945

Kumar, S., S. Luthra, K. Govindan, N. Kumar, and A. Haleem. 2016. 'Barriers in Green Lean Six Sigma Product Development Process: An ISM Approach.' Production Planning and Control 27 (7-8): 604-20. doi:10.1080/09537287.2016.1165307.

Labuschagne, C., A.C. Brent, R.P.G. Van Erck. 2005. 'Assessing the sustainability performances of industries.' Journal of Cleaner Production. 13: 373-385. doi:10.1016/j.jclepro.2003.10.007

Langfield-Smith, K., H. Thorne, and R. Hilton. 2009. 'Management Accounting: An Australian Perspective.', 6th ed., McGraw-Hill, Sydney.

Lee K.H., and R.F. Saen. 2012. 'Measuring corporate sustainability management: A data envelopment analysis approach.' International Journal of Production Economics. 140: 219-226.

Leite, L. R.; J. B., Araujo, and R.A. Martins. 2011. 'Sustentabilidade como direcionador 
de evolução dos sistemas de medição de desempenho.' NAVUS, Revista de Gestão Tecnológica. Florianópolis, SC. 1 (1): 35-50.

León, H. C. M., and J. Calvo-Amodio. 2017. 'Towards Lean for Sustainability: Understanding the Interrelationships between Lean and Sustainability from a Systems Thinking Perspective'. Journal of Cleaner Production 142: 4384-4402. doi:10.1016/j.jclepro.2016.11.132.

Linnenluecke, M. K., and A. Griffiths. 2013. 'Firms and sustainability: Mapping the intellectual origins and structure of the corporate sustainability field.' Global Environmental Change 2: 382-391.

Luzzini, D., E. Brandon-Jones, A. Brandon-Jones, and G. Spina. 2015. 'From Sustainability Commitment to Performance: The Role of Intra- and Inter-Firm Collaborative Capabilities in the Upstream Supply Chain'. International Journal of Production Economics 165: 51-63. doi:10.1016/j.ijpe.2015.03.004.

Meng, X.H., S.X. Zeng, J. J. Shi, G.Y. Qi, and Z.B. Zhang. 2014. 'The relationship between corporate environmental performance and environmental disclosure: An empirical study in China.' Journal of Environmental Management 145 (1): 357-367.

Miguel, P. A. C. 2005. Recomendações na Adoção de Estudo de Caso como Abordagem Metodológica. XII SIMPEP - Bauru, SP, Brasil, 7 a 9 de Novembro.

Morioka, S.N., and M.M. Carvalho. 2014. 'Measuring sustainability in practice: Exploring the inclusion of sustainability into corporate performance systems in Brazilian case studies.' Journal of Cleaner Production 136: 123-133. doi:10.1016/j.jclepro.2016.01.103

Nagalingam, S. V., S. S. Kuik, and Y. Amer. 2013. 'Performance Measurement of Product Returns with Recovery for Sustainable Manufacturing'. Robotics and $\begin{array}{llll}\text { Computer-Integrated } & \text { Manufacturing } & 29 & \text { (6): }\end{array}$ doi:10.1016/j.rcim.2013.05.005.

Norman W., and C. Macdonald. 2004. 'Getting to the Bottom of Triple Bottom Line.' Business Ethics Quarterly 14 (2): 243-262.

Pestana D. D., and S. F. Velosa 2006. Introdução à probabilidade e à estatística. Volume I. $2^{\mathrm{a}}$. edição. Lisboa: Edição da Fundação Calouste Gulbenkian, v. 1.

Powell, D., S. Lundeby, L. Chabada, and H. Dreyer. 2017. 'Lean Six Sigma and Environmental Sustainability: The Case of a Norwegian Dairy Producer.' International Journal of Lean Six Sigma 8 (1): 53-64. doi:10.1108/IJLSS-06-20150024.

Prasad, S., D. Khanduja, and S. K. Sharma. 2016. 'An Empirical Study on Applicability of Lean and Green Practices in the Foundry Industry'. Journal of Manufacturing Technology Management 27 (3): 408-26. doi:10.1108/JMTM-08-2015-0058.

Psychogios, A. G., and L. K. Tsironis. 2012. 'Towards an Integrated Framework for Lean Six Sigma Application: Lessons from the Airline Industry'. Total Quality Management \& Business Excellence 23 (3-4): 397-415. doi:10.1080/14783363.2011.637787.

Puvanasvaran, P., R. K. S. Tian, and S. A. L. Vasu. 2014. 'Lean Environmental Management Integration System for Sustainability of ISO 14001:2004 Standard Implementation'. Journal of Industrial Engineering and Management 7 (5). Universitat Politecnica de Catalunya: 1124-44. doi:10.3926/jiem.907. 
R Development Core Team 2017. R: A Language and Environment for Statistical Computing. Vienna, Austria: R Foundation for Statistical Computing. Retrieved from http://www.R-project.org

Rashidi, K., and R. F. Saen. 2015. 'Measuring Eco-Efficiency Based on Green Indicators and Potentials in Energy Saving and Undesirable Output Abatement'. Energy Economics 50 (July): 18-26. doi:10.1016/j.eneco.2015.04.018.

Razali, N. M., and Y. B. Wah. 2011. 'Power Comparisons of Shapiro-Wilk , Kolmogorov-Smirnov, Lilliefors and Anderson-Darling Tests'. Journal of Statistical Modeling and Analytics 2 (1): 21-33.

Sagnak, M., and Y. Kazancoglu. 2016. 'Integration of Green Lean Approach with Six Sigma: An Application for Flue Gas Emissions.' Journal of Cleaner Production 127: 112-18. doi:10.1016/j.jclepro.2016.04.016.

Shah, R., and Ward, P. T. 2003. 'Lean Manufacturing: Context, Practice Bundles, and Performance.' Journal of Operations Management 21 (2): 129-149.

Silva, C., P. Vaz, and L. M. Ferreira. 2013. The Impact of Lean Manufacturing on Environmental and Social Sustainability: A Study Using a Concept Mapping Approach. IFAC Proceedings Volumes (IFAC-PapersOnline). Vol. 6. IFAC. doi:10.3182/20130911-3-BR-3021.00080.

Simpson, D. F., and D. J. Power. 2005. 'Use the Supply Relationship to Develop Lean and Green Suppliers'. Supply Chain Management: An International Journal 10 (1): 60-68. doi:10.1108/13598540510578388.

Singh, R. K., H.R. Murty, S.K. Gupta, and A.K. Dikshit. 2007. 'Development of composite sustainability performance index for steel industry.' Ecological Indicators 7: 565-588.

Sureeyatanapas P., J. B. Yang, and D. Bamford. 2015. 'The sweet spot in sustainability: a framework for corporate assessment in sugar manufacturing.' Production Planning \& Control 26 (13): 1128-1144 http://dx.doi.org/10.1080/09537287.2015.1015470

Schrettle, S., A. Hinz, M. Scherrer-Rathje, and T. Friedli. 2014. 'Turning sustainability into action: Explaining firms' sustainability efforts and their impact on firm performance.' International Journal of Production Economics. 147: 73-84.

Thieme, J., M.B. Royne, S. Jha, M. Levy, and W.B. McEntee. 2015. 'Factors affecting the relationship between environmental concern and behaviors.' Marketing Intelligence \& Planning 33(5): 675 - 690

Thomas, A.J., M. Francis, R. Fisher, and P. Byard. 2016. 'Implementing Lean Six Sigma to overcome the production challenges in an aerospace company.' Production Planning \& Control 27 (7-8): 561-603. doi:10.1080/09537287.2016.1165300

Valiente, J.M.A., C.G. Ayerbe, and M. S. Figueras. 2012. 'Social responsibility practices and evaluation of corporate social performance.' Journal of Cleaner Production 35: 25-38.

Veleva, V., and M. Ellenbecker. 2001. 'Indicators of sustainable production: framework and methodology.' Journal of Cleaner Production 9: 519-549.

Verrier, B., B. Rose, E. Caillaud, and H. Remita. 2014. 'Combining Organizational Performance with Sustainable Development Issues: The Lean and Green Project Benchmarking Repository.' Journal of Cleaner Production 85 (December): 83-93. doi:10.1016/j.jclepro.2013.12.023. 
Vlachos, I. 2015. 'Applying Lean Thinking in the Food Supply Chains: A Case Study'. Production Planning \& Control $26 \quad$ (16): $1351 \quad$ - 1367. doi:10.1080/09537287.2015.1049238.

Wu, Z., and M. Pagell. 2011. 'Balancing priorities:decision-making insustainable supply chain management.' Journal of Operations Management 29 (6): 577-590.

Yusuf, Y.Y., A. Gunasekaran, A. Musa, N.M. El-Berishy, T. Abubakar, and H.M. Ambursa, 2013. 'The UK oil and gas supply chains: An empirical analysis of adoption of sustainable measures and performance outcomes.' International Journal of Production Economics 146 (2): 501-514. doi:10.1016/j.ijpe.2012.09.021

Zhan, Y., K. H. Tan, G. Ji, L. Chung, and A. S. F. Chiu. 2015. 'Green and Lean Sustainable Development Path in China: Guanxi, Practices and Performance'. Resources, Conservation and Recycling. 128 (1): 240-249 doi:10.1016/j.resconrec.2016.02.006. 